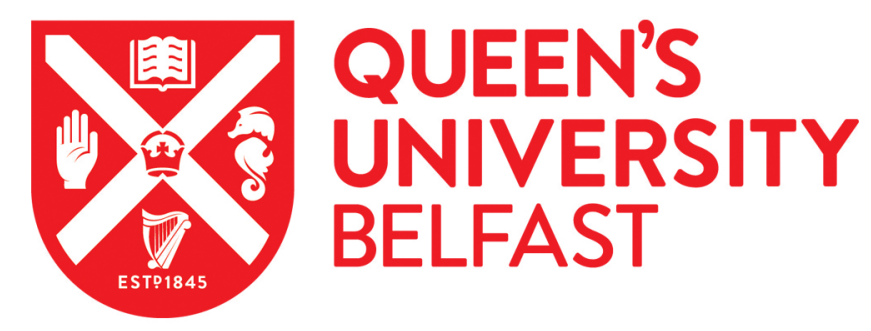

\title{
National identification and anti-immigrant prejudice: Individual and contextual effects of national definitions
}

Pehrson, S., Vignoles, V., \& Brown, R. (2009). National identification and anti-immigrant prejudice: Individual and contextual effects of national definitions. Social Psychology Quarterly, 72(1), 24-38.

https://doi.org/10.1177/019027250907200104

Published in:

Social Psychology Quarterly

Document Version:

Peer reviewed version

Queen's University Belfast - Research Portal:

Link to publication record in Queen's University Belfast Research Portal

\section{General rights}

Copyright for the publications made accessible via the Queen's University Belfast Research Portal is retained by the author(s) and / or other copyright owners and it is a condition of accessing these publications that users recognise and abide by the legal requirements associated with these rights.

Take down policy

The Research Portal is Queen's institutional repository that provides access to Queen's research output. Every effort has been made to ensure that content in the Research Portal does not infringe any person's rights, or applicable UK laws. If you discover content in the Research Portal that you believe breaches copyright or violates any law, please contact openaccess@qub.ac.uk. 
NATIONAL IDENTIFICATION AND ANTI-IMMIGRANT PREJUDICE:

INDIVIDUAL AND CONTEXTUAL EFFECTS OF NATIONAL DEFINITIONS*

Samuel Pehrson

(University of Limerick, Ireland)

Vivian L. Vignoles

Rupert Brown

(University of Sussex, UK)

* The research was carried out as part of the first author's doctoral research at the University of Sussex, UK, which was funded by an Economic and Social Research Council studentship (ref: PTA-030-2004-00746). The authors wish to thank Mirona Gheorghiu and 4 anonymous reviewers for their helpful comments on earlier drafts of this paper.

This is an author-produced, peer-reviewed article that has been accepted for publication in Social Psychology Quarterly but has not been copyedited. The publisher-authenticated version is available at http://www.asanet.org/.

Reference: Pehrson, S., Vignoles, V., \& Brown, R. (2009). National identification and antiimmigrant prejudice: Individual and contextual effects of national definitions. Social Psychology Quarterly, 72, 24-38. 
National identification and anti-immigrant prejudice: Individual and contextual effects of national definitions.

We examined the relationship between national identification and anti-immigrant prejudice in a multilevel analysis of ISSP survey data from 37030 individuals in 31 countries. It is argued that this relationship depends on how national groups are defined by their members. Across the 31 national samples, the correlation between national identification and prejudice ranged from weakly negative (-.06) to moderately positive $(+.37)$. The relationship was significantly stronger in countries where people on average endorsed a definition of national belonging based on language, and weaker where people on average define the nation in terms of citizenship. These effects occurred at a national rather than individual level, supporting an explanation in terms of the construction of nationality that prevails in a given context. Endorsement of the ancestry-based criteria for nationality was positively associated with prejudice, but only at the individual level. 
The topic of immigration has been receiving increasing interest from social scientists over the past decade. This is not surprising given the considerable number of people who are now migrating across international borders (Global Commission on International Migration, 2005), and the consequent importance of immigration as a political issue in many countries. The range of possible reactions to immigration among the populations of receiving countries lends itself to evaluating and refining theories of prejudice and intergroup relations.

The fact that migration is a truly global phenomenon, with many different countries across every continent now receiving international migrants, presents the social scientist with the possibility of cross-national comparisons. It allows us to examine both consistency and variability in the psychological processes driving people's reactions to immigration, since these occur in national contexts with diverse economic conditions, histories of immigration, conceptions of nationality, and so forth. Such comparisons have highlighted some remarkable consistency in the correlates of anti-immigrant prejudice across national contexts, with factors such as economic deprivation, lack of contact with immigrants, perceived threat and political conservatism consistently predicting opposition to immigration (Pettigrew, Wagner, and Christ in press). However, the focus of the current paper is on the variability. Specifically, we seek to demonstrate that, although national identification is often associated with anti-immigrant prejudice, there is variability in the relationship, and that this variability is partially accounted for by the various ways in which nations are defined. 
Nationalism is of interest across several disciplines, including history, political science and sociology, especially since Gellner (1983/2006) and Anderson's (1983/1991) seminal contributions. It has been conceptualized in various ways, for example as the principle that nationhood and statehood should be congruent, or the project of actualising national unity, sovereignty and identity that follows from this principle (Gellner 1983/2006; Hobsbawm 1990/1992; Ignatieff 1993; Smith 2001). Greenfeld (1996) understands nationalism as culture, in the sense of a shared representation of ideal social relations, in which the nation is envisaged as the basic source of sovereignty and object of solidarity.

The main concern for psychologists is usually individuals' identification with a national group that they belong to (e.g. Mummendey, Klink, and Brown 2001). Thus, psychologists tend to take the existence of nations for granted (for critiques see: Billig 1995; Reicher and Hopkins 2001), and to consider them as one of the many group memberships that people have. This is in contrast to scholars in other disciplines, who have focused more on the unique qualities of nationalism by tracing its emergence as a political principle (Gellner 1983/2006), or examining the primary importance of nationalism as the cultural underpinning of other elements of modernity, such as bureaucratic government (i.e. the state), capitalism and science (Greenfeld 1996; 2006).

These approaches can be complimentary, and the difference stems from the respective focus of each discipline rather than any actual disagreement about the nature of nationalism. Social psychologists focus on the meaning that a given social reality has for the individual, and the processes through which individuals shape and are shaped by the social world (Allport 1954a). While noting the historical contingency of the nation and the nation-state, we can also acknowledge that nations 
have a reality for the individual. An account of the social identity processes that operate within this reality is important if we are to understand, for example, the implications of identifying with a national group for one's attitudes towards immigrants. Nevertheless, we should remain aware that social identities have particular meanings that derive from the wider context (Reicher and Hopkins 2001).

It is still unclear how ingroup identification in general is related to prejudice, even though this has been of interest to social scientists for over 100 years (Allport 1954b; Brewer 1999; Brown and Zagefka 2005; Sumner 1906). Social identity theory could be read to imply that ingroup identification should be associated with higher levels of prejudice, since outgroup derogation is means of achieving positive distinctiveness for the ingroup (Tajfel and Turner 1979). However, intergroup bias resulting from the motive for positive ingroup distinctiveness is not the same as actual negativity towards an outgroup, which social identity theory is less able to explain (Brown 2000). Reicher and Hopkins (2001), meanwhile, criticize any attempt to establish a generic relationship between ingroup identification and prejudice as misguided, since it ignores the particular definitions and content of social identities.

Jackson, Brown, Brown and Marks (2001) suggest that a positive relationship between national identification and negative attitudes towards immigrants might be expected because people who identify with the nation have a greater concern for the national interest. This is problematic because it assumes that immigration is inevitably perceived as bad for national interest.

Empirical evidence on the national identification-prejudice relationship is mixed. On the one hand, a number of studies conducted in various national contexts indicate a positive relationship between national identification and negative attitudes towards immigrants (Bourhis and Dayan 2004; Pettigrew 2006b; Pettigrew, Wagner, 
and Christ in press; Verkuyten 2004). However, Jackson et al. (2001) also report evidence that the relationship is not straightforward. Controlling for a range of demographic variables and perceived threat, national pride showed no consistent association with willingness to 'send immigrants back', as standardized betas ranged from .03 to -.09 across 15 national samples from the 1997 Eurobarometer survey. The authors conclude that the relationship is 'complex' and 'needs further investigation' (p. 448). Thus, there appears to be no clear theoretical or empirical justification to suggest a general association between national identification and anti-immigrant prejudice.

National definitions and the identification-prejudice relationship

It is possible to make sense of this apparently complex picture by considering the fact that nationhood is not represented in the same way in all countries. Depending on whether or not national group membership is defined in a way that excludes immigrants, we can expect national identification and attitudes towards immigrants to relate differently. Where the shared meaning of nationality is potentially inclusive of immigrants, there is no incompatibility between national identification and openness to immigrants. In such cases, there is no reason to expect national identification to be correlated with prejudice towards them. However, where nationhood is commonly understood in an exclusive way, national identification implies opposition to immigration, so should be correlated with prejudice. Therefore, the relationship between national identification and prejudice depends on the definition of nationality that prevails in a given context. 
In the study of nationalism, a common distinction is made between ethnic and civic nationalism, whereby ethnic nationalism defines the nation in terms of some supposed shared ancestral, linguistic and/or cultural homogeneity and distinctiveness. Civic nationalism on the other hand defines nationality in more voluntaristic terms, using criteria such as citizenship, as well as the institutional commitments and participation that this entails (Smith, 2001). To define the national group is to define the bounds of collective sovereignty and equality, so national definitions have immense political significance (Greenfeld 2006). Therefore, within ethnic nationalism, but not civic nationalism, nationality is defined in such a way that immigrants are excluded.

According to Hobsbawm (1990/1992), civic nationalism was the first to appear historically, epitomized by the French and American revolutions. Ethnic nationalism developed later, in the late $19^{\text {th }}$ century, partly as a result of the theories of 'race' that were popular at that time. It was during this period that both language and descent first became closely associated with the concept of 'nation'. He also notes that the nationalism of the anti-colonial independence movements is typically more civic than ethnic. Civic nationalism has also been characterised as more 'Western', with the ethnic form being 'Eastern' nationalism, although survey data appears to contradict this East-West distinction (Shulman 2002). Nonetheless, one can expect these conceptions of who can belong to the national group to be endorsed differently by the populations of different countries.

A further distinction can be drawn between a strictly 'ethnic' understanding of nationality based on ancestry, and a more 'cultural' definition based on criteria such as language (Shulman 2002). Both ancestry and language as bases for nationality are historically associated with xenophobic nationalist movements of the late $19^{\text {th }}$ century 
(Hobsbawm 1990/1992). Although more open to immigrants than ancestry, since language can be acquired, the national definition along linguistic lines still disfavours immigrants in many cases.

We suggest that variability in how the nation is popularly conceived is crucial in accounting for the contextual variability in how national identification is related to anti-immigrant prejudice. Furthermore, we argue that this variability is driven by a genuinely collective process. That is, we suggest that it is the extent to which a definition of the nation prevails in any given national context that determines whether or not the same people who espouse anti-immigrant sentiments also show higher national identification. National identification and opposition to immigration can be seen as positions that people take within a wider discursive context (Billig 1991). The dominance of particular constructions of nationality affects which of these positions are possible and which are not (Parker 1992). The representation of the nation that dominates in any given context affects the meaning of national identification, and whether or not it is consistent with an open attitude towards immigrants. This difference in construction across contexts should therefore account for differences in the extent to which national identification and prejudice co-vary.

Maddens, Billiet and Beerten (2000) argue along similar lines that different social representations of the nation result in differences between Flemish and Walloon people in Belgium in the relationship between national identification and negative attitudes towards immigrants. They argue that, because Flemish identity is more ethnic in content, while Walloon identity is more civic, Walloon and Flemish populations should show opposite relationships between national identification and prejudice. This is supported: among the Flemish, prejudice was positively associated 
with identification with Flanders, whereas for Walloon people, it was negatively associated with identification with Wallonia.

However, Maddens et al.'s (2000) evidence is insufficient for two reasons. Firstly, the 'national identification' measure used in the study actually consisted mainly of participants' preferences for political decision-making and governance at either the Belgian or regional level. It therefore presented a forced choice between national and sub-national categories and was not a true measure of national identification. Secondly, with only two macro-level units (Flanders and Wallonia) the conclusion that the difference between them is due to differences in the social representations, rather than any other possible difference between the sub-national units, is speculative.

Stronger evidence is provided by Weldon's (2006) analysis of tolerance and citizenship regimes using survey data from all EU member states in 1997. Respondents' identification with their nation state rather than Europe was found to be related to low political and cultural tolerance towards minority groups only in states with citizenship policies that are based on ethnic criteria. The study therefore provides compelling evidence for the moderation of the identification-prejudice relationship by citizenship regimes.

However, there are also some limitations to the conclusions that can be drawn from Weldon's (2006) analysis. As with Maddens et al. (2000), the national identification measure forces respondents to choose between two objects of identification, in this case between the nation-state and Europe. Using such a measure, identification with the nation cannot be distinguished from dis-identification with Europe, which is not necessarily the same thing. 
Furthermore, as Weldon himself notes, although some countries have official legal policies regarding who is entitled to citizenship, which he categorizes as civic or ethnic, there can be multiple contradictory definitions of nationhood within any one country that are endorsed to varying degrees by the population. For example, in Great Britain, which is categorized by Weldon as having a civic citizenship regime, there is evidence of both civic and ethnic representations being present, with some individuals endorsing only a civic definition of the nation, and others endorsing a combination of the civic and ethnic definitions (Tilly, Exley \& Heath 2004). Thus, even where citizenship policies can be placed in discrete categories, it remains an open empirical question whether or not the civic, ethnic and cultural representations of nationhood endorsed by the population are really mutually exclusive at either the individual or collective level.

Individual variation in the definition of one's national group also has consequences for the relationship between identification and prejudice. Pehrson, Brown \& Zagefka (in press), for example, report data from English adolescents showing that national identification is associated with negative feelings and intentions towards asylum seekers, but only to the extent that participants endorse an essentialist ('ethnic') definition of the nation group. Among the individuals who reject this definition, no relationship is observed. Therefore, national groups can be defined differently among individuals within the same country, and these differences appear to influence the identification-prejudice relationship.

The current study 
We seek to show that the definition of nationality that is generally endorsed in one's country moderates the relationship between identification and prejudice, above and beyond effects of what one actually endorses as an individual. This is an important conceptual distinction, since it concerns the issue of whether a genuinely collective process, rather than the aggregation of individual processes, is involved. It is also distinction that can be made empirically using appropriate methodology.

In order to address this issue, we make use of representative survey data from 31 countries. This allows us to examine the relationship between national identification and anti-immigrant prejudice in each country. The dataset is well suited to a multilevel analysis of how the individual-level relationship between national identification and prejudice varies across the national samples, and accounting for this variability in terms of the differences between countries in the representations of national group membership. Such a multilevel approach to the topic is valuable because, on a theoretical level, both individual and broader societal level processes are of interest to psychologists studying prejudice (Allport 1954b), and antiimmigrant prejudice in particular (Pettigrew 2006b). Multilevel statistics allow us to model both kinds of process simultaneously and, crucially, to analyse how individuallevel relationships are moderated by societal or institutional factors. Pettigrew (2006a) asserts that multilevel statistics should become an essential tool for systematically contextualising psychological findings on prejudice, which is precisely the aim of the current research.

Other multilevel analyses of survey data on attitudes about immigration have found that, for example, the role of contact in reducing prejudice towards migrants appears to be most critical in countries with a high proportion of foreign nationals in the population (McLaren 2003). Coenders and Scheepers (2003) find that the 
relationship between education and ethnic exclusionism is smallest in recently established democracies. The method can therefore reveal potentially informative contextual moderation of individual-level effects.

Across different nations, we expected to observe a range of different relationships between national identification and prejudice, ranging from none at all to moderately positive. We expected this variation to be associated with the definition of the national group that is endorsed in each country. The national identificationprejudice relationship should be weakest where the civic definition of nationality is widely endorsed, and strongest where the ethnic or cultural definitions are widely endorsed.

\section{METHOD}

\section{Dataset}

The study used data from the International Social Survey Programme (ISSP) 2003 module on national identity. ${ }^{1}$ The dataset included 31 national samples that provided all of the indicators required for the current analysis, not including the Philippines, which was excluded because of very poor reliability on the prejudice measure. These included countries from Western and Eastern Europe, North and South America and East Asia. Therefore, despite the omission of Africa (South Africa is included in the ISSP, but did not provide all the items required for the current study), the dataset

\footnotetext{
${ }^{1}$ The ISSP is a self-funding annual program that coordinates cross-national surveys on social scientific themes. The data from the ISSP is merged and archived by the Zentralarchiv für Empirische Sozialforschung, University of Cologne. Detailed information on this programme and access to the datasets can be found at http://www.issp.org/.
} 
provides a broad geographical range of countries. East and West Germany are included as separate samples in the ISSP. This distinction was retained, because the diverse political histories and experiences of immigration were judged to justify their consideration as separate samples in the current study. The sampling method in each country approximates a true random sample of each population. Possible sampling biases vary by country, and are reported in the ISSP codebook (Central Archive for Empirical Social Research 2004). After removing individuals who did not provide all the responses that were required for the analysis (5.5 percent), and those who were not citizens of the country in which the survey was carried out (2.6 percent), the total sample size was 37,030. National sample sizes were between 412 and 2,181.

\section{Measures}

Anti-immigrant prejudice was computed as the mean of 6 items tapping a negative perception of immigrants. Five of these were rated on a 5-point scale indicating agreement from 'agree strongly' to 'disagree strongly'. These were: 'Immigrants increase crime rates'; 'Immigrants are generally good for [country]'s economy' (reverse coded); 'Immigrants take jobs away from people who were born in [country]'; 'Immigrants improve [country] society by bringing in new ideas and cultures' (reverse coded); and 'Government spends too much money assisting immigrants']. The sixth item read: 'Do you think the number of immigrants to [country] nowadays should be...', and was rated on a 5-point scale from 'increased a lot' to 'reduced a lot'. The scores were coded such that high scores indicate a more negative perception of immigrants. The national level variable was computed from 
the individual level scores as the mean within each national sample. The scale showed good reliability at both individual $(\alpha=.81)$ and national $(\alpha=.82)$ levels. Alpha for each country ranged from .65 to .88 .

Age, years of education and family income were taken as control variables. Missing values for education (11.6 percent) and income (15.4 percent) were imputed from observed values of the other independent variables using regression imputation. This was done separately within each national sample. Carpenter and Kenward (2005) note that regression coefficients based on such imputed values can be misleading, and we suggest caution in interpreting the coefficients for these two variables. Our concern here was to avoid spurious relationships between the main variables of interest by controlling for the possible effects of age, education and income in our analysis. For a more comprehensive examination of the relationship between education and prejudice, we refer the reader to Coenders and Scheepers (2003).

National identification was computed as the mean of 2 items: 'How close do you feel to [country]?' and 'How proud are you of being [nationality]?', which were rated on a 4-point scale. Alphas for this 2-item index were .55 at the individual level and .67 at the national level. Alpha for each country ranged from .20 to .68. Although an alpha of .20 indicates poor reliability, we must emphasise that this is not surprising for a 2-item scale. Furthermore, controlling for possible effects of the variation in reliabilities in the analysis did not fundamentally alter the results.

A set of items in the ISSP questionnaire was used to measure national definitions. These were introduced by the following instruction: 
"Some people say the following things are important for being truly [nationality]. Others say they are not important. How important do you think each of the following is?"

Respondents then rated the importance of the various criteria on a scale ranging from 1 (very important) to 4 (not at all important), but we reversed these so that high scores indicate higher importance of the criteria. Three of the criteria were considered to be clear indicators of the identity content dimensions discussed in the nationalism literature. Having citizenship of the country was taken as an indicator of the 'civic' definition. Speaking the language of the country was taken as an indicator of the 'cultural' definition. Finally, having ancestry of the nationality was taken as an indicator of the 'ethnic' definition. ${ }^{2}$ These single indicators were chosen rather than attempting to form scales because of inconsistent factor structures across the 31 countries. The national level indices for these identity content variables were the mean scores of all participants in each national sample.

Gross Domestic Product (GDP) per capita for each country in 2003 was obtained from the Human Development Index (United Nations, 2004).

\section{RESULTS}

Strength of the national identification-prejudice association

\footnotetext{
${ }^{2}$ The other criteria that respondents were asked about (not used in the current analysis) were being born in the country, living most of ones life in the country, religion, respecting institutions, and feeling [nationality]. The overall score across all dimensions was 3.15 .
} 
The simple correlation coefficients between national identification and prejudice give an indication of the variation in this relationship across the 31 national samples (table 1). A significant positive relationship was observed in 18 countries. The strongest positive relationships were observed in Switzerland, West Germany and Denmark, where the correlation was moderate. Negative correlations were observed in Venezuela and Canada, but these were both very small, and reached significance only in Venezuela. The median identification-prejudice correlation was .13. Therefore, the relationship between national identification and prejudice ranged from a very weak negative relationship to a moderate positive relationship, with a weak positive relationship on average.

Overall correlations between national identification, prejudice and the national definitions at both individual and national levels are shown in table 2. It is apparent that the relationships between these variables differ at individual and nation levels of analysis. For example, national identification and all three definitions are positively related to prejudice at the individual level, while at the national level, both national identification and the civic definition are negatively related to prejudice.

[TABLES 1 AND 2 ABOUT HERE]

Accounting for the variation in the identification-prejudice relationship using multilevel regression 
In order to test our hypothesis that the identification-prejudice relationship depends on national level differences in the construal of nationality we carried out multilevel regression analysis using HLM 6 (Raudenbush, Bryk, and Congdon 2007). This makes it possible to analyse variance at both individual and national levels within a single model, and to test our hypothesized nation-level moderation of individual-level relationships.

National identification and the definition variables were all centred at the grand mean. In multilevel regression, centering is essential if we are to be able to interpret the variance in the slope between groups, as well as the path coefficients for any variable involved in cross-level interactions. This is because the values obtained are those estimated when all other parameters are equal to zero (Hox 2002). Zero must therefore be a meaningful value. Grand mean centering makes zero the mean of the variable. Education and income were centred at the national mean (rather than the overall mean) because these variables were not involved in interactions, had fixed slopes, and were considered to be more meaningful in relation to co-nationals than in relation to the entire dataset.

[TABLE 3 ABOUT HERE]

In total, 5 predictive models plus one null model were estimated (table 3$).^{3}$ The null model consisted only of an intercept and error terms for the individual level

\footnotetext{
${ }^{3}$ The model reported here was un-weighted, meaning that the model gives equal weight to each individual case rather than each country. Weighting at level one, such that each country has equal influence on the analysis regardless of sample size, yields the same pattern of results.
} 
and national level variance in prejudice. This provided variance components of .59 at the individual level and .07 at the national level, and a deviance of 84,427 (3 d.f.), which serve as a baseline for evaluating the predictive models. The reduction in variance components from this baseline was used to estimate the modelled variance $\left(\mathrm{R}^{2}\right)$ statistics at both levels for each model. ${ }^{4}$ Reductions in the deviance of each successive model (i.e. the likelihood ratio) were used to evaluate the improvement in model fit. The likelihood ratio follows a chi-square distribution and could therefore be tested for statistical significance. Beta estimates were tested for significance based on robust standard errors.

In model 1, we added the demographic control variables (age, education and family income) and GDP at the national level. These significantly decreased the deviance statistic, indicating an improvement in the fit of the model. The beta estimates indicated that older respondents reported significantly more prejudice than younger respondents, and that education and family income both had a significant negative relationship with prejudice.

In model 2 we added national identification at both the individual and national levels. These further improved the fit of the model. The beta values indicated that, at the individual level, national identification had a weak positive overall relationship with anti-immigrant prejudice. However, at the national level, the relationship is

\footnotetext{
${ }^{4}$ Because variance is modelled at two levels (within and between national samples), we obtain separate $\mathrm{R}^{2}$ values for each level. These can be used to evaluate how much variance is explained at each level by each model. A total $\mathrm{R}^{2}$ statistic is derived from these, which indicates the overall variance explained by the model (Hox, 2002). It should be noted these are estimates. They therefore do not carry the same weight that they do in traditional multiple regression, but are useful interpretative tools.
} 
negative. That is, people in countries with high mean levels of identification reported lower levels of prejudice.

In model 3, we added the national definition variables (citizenship, language and ancestry definitions) at both individual and national levels. These again improved the fit of the model. At the individual level, citizenship and ancestry definitions were positively associated with prejudice, although the relationship for citizenship was very weak. At the national level prejudice was negatively associated with the citizenship definition.

In model 4, we added the three terms representing the interaction between national identification and each national definition variable at the individual level. GDP was also added as a national-level predictor of the identification-prejudice slope. These significantly improved the fit of the model, with GDP positively predicting a stronger identification-prejudice relationship. The individual-level interaction effects were negligible. The purpose of this step was simply to control for the moderating influence of GDP and individual differences in national definition, so that we could then evaluate the unique contribution of the national level moderation of the identification-prejudice relationship by national definitions in the following step.

Thus, in the final model (model 5) we added cross-level interactions representing the moderation of the identification-prejudice relationship by the aggregated (national level) national definition variables. This step significantly improved the fit of the model. As expected, national differences in the endorsement of the citizenship definition significantly predicted the identification slope, with higher endorsement associated with a less positive identification-prejudice relationship. Also as expected, the linguistic definition shows the opposite pattern, predicting a stronger 
identification-prejudice relationship. These cross-level interactions were significant. The ancestry definition did not moderate the slope as we had expected.

\section{DISCUSSION}

As predicted, national level differences in national definitions do account for variation between countries in the national identification-prejudice relationship. National identification predicts prejudice most positively in those countries in which people on average regard speaking the national language as more important, and citizenship as less important, as criteria for being considered a national of that country. The relationship is also more positive in countries with higher GDP. Furthermore, the multilevel method allows us to conclude that these contextual effects genuinely occur at a collective level. They are not a consequence of aggregated individual level effects. Indeed, the individual level interaction terms are negligible in magnitude. In other words, the identification-prejudice relationship depends on being in a nation in which these criteria are generally considered important, rather than being an individual for whom they are important. Moreover, the fact that the definitions moderate in different directions confirms that the results cannot be explained away in terms of national differences in response bias (Smith 2004).

At the individual level, support for the ethnic criterion showed a moderate positive association with prejudice, confirming existing findings (Rothi et al. 2005). The civic criterion had a weak positive relationship to prejudice. While this should be interpreted with consideration of the strong national-level effects of this dimension in the opposite direction, it confirms that endorsement of any of the criteria involves 
some level of exclusivity (Green 2007). Individuals with lower income and less education than their co-nationals are more prejudiced, in line with previous findings (Pettigrew 2006b), although these relationships are also weak.

The results are consistent with our central argument that there is no generic relationship between national identification and anti-immigrant prejudice, and that the relationship that is observed in any given context depends on how the nation is defined by the population. As we have seen, where nationality is understood in terms of citizenship, the identification-prejudice relationship is close to zero (and in some cases negative), but where it is understood in terms of language, the relationship is moderate and positive. This makes sense if one considers that nationalism calls for congruence between the national group and the state. Identification with a culturally defined nation implies opposition to immigration more strongly than identification with a nation defined by shared citizenship. The prevalence of these different kinds of national group construal varies across countries, and so the relationship between national identification and prejudice varies systematically with this.

This goes some way in clarifying the existing evidence on national identification and prejudice in the literature, which has until now been unclear (Jackson et al. 2001; Pettigrew, Wagner, and Christ in press). It also informs the broader debate on the relationship between ingroup affiliations and prejudice (Allport 1954b; Brewer 1999; Brown and Zagefka 2005), adding weight to the argument that the study of social identity processes should not be divorced from identity content (Livingstone and Haslam 2008; Reicher 2004; Reicher and Hopkins 2001). The study demonstrates that the consequences of identifying with a group can be better understood by paying closer attention to the group definitions that dominate in any given context. In the case of nationality, these definitions are related to whether or not 
immigration constitutes subversion of the nation-state, and, by implication, whether or not individuals who identify with the national group are also hostile towards immigrants.

In addition to clarifying the relationship between identification and prejudice at the individual level, our analysis reveals that national identification is negatively associated with prejudice at the national level. This remains marginally significant when controlling for the national definition variables. Although not expected, this intriguing observation further undermines any assumption of a straightforward positive relationship between identifying with one's national group and hostility towards immigrants. It suggests that, although having a high level of national identification can be associated with higher levels of prejudice (depending on the contextual conditions described above), living in a country in which national identification on average is high has the opposite association. That is, having conationals who identify strongly with the nation is associated with having more tolerant attitudes towards immigrants.

We can speculate as to why this negative relationship occurs. One interpretation, for example, is in terms of threat. In contexts where levels of national identification are generally low, people may perceive national identity to be particularly vulnerable, with a consequent increase in the perception of identity threat associated with immigration. In countries with high average levels of national identification, on the other hand, people may perceive national identity to be secure, and therefore less sensitive to immigration as a threat to nationhood. While this is an interesting possibility, it should not be prematurely assumed that official attempts to increase overall national identification, even in an apparently inclusive way, would necessarily improve attitudes towards immigrants. Such efforts could actually do the 
opposite if they lead to the impression that government intervention is required to counter a threat from immigration to national identity, solidarity or 'cohesion' (Cheong, Edwards, Goulbourne \& Solomos, 2007).

Although further research is necessary to untangle this particular relationship, the finding does illustrate that relationships occurring between variables at the macrolevel, such as between countries, are often distinct from individual level relationships. In the case of the identification-prejudice relationship, the two levels actually show associations in opposite directions. Without analysing the variance at both levels simultaneously, this would not have been apparent, and we may have mistakenly extended the overall finding from the individual level to draw conclusions about national level phenomena. For example, we might have assumed that countries with high national identification are high in prejudice, when in fact the reverse is true. This is known as the 'compositional fallacy' (Pettigrew 2006a), and the multilevel approach employed here is a powerful means to avoid it.

A further unpredicted finding is that national identification predicts prejudice more strongly in countries with high GDP than in those with low GDP. This is not surprising given that one can reasonably assume that wealthy countries are likely to be receiving immigrants who are relatively poor, compared to their own populations. Immigrants are therefore more likely to be perceived as an economic burden rather than a benefit to the country. This would explain why national identification is more closely linked to anti-immigrant prejudice in wealthy countries.

Our analysis also clarifies the relationship between different national definitions. Civic and cultural/ethnic definitions of national group membership might appear in opposition to one another, such that a given national group defines itself in either one way or another. However, our data suggest that the importance of one kind 
of criteria does not appear to diminish the importance of others. This is not to negate the usefulness of understanding civic and ethnic nationalism as conceptually and historically distinct phenomena, but rather to note that these apparently contradictory ideal types are not fundamentally in conflict with one another at the level of popular attitudes.

Our finding that the support for the linguistic definition of nationality is associated with a stronger identification-prejudice relationship is interesting, given that language is not as clearly an inclusive or exclusive definition as citizenship and ancestry respectively. Brubaker (1990) suggests that cultural homogeneity can form part of a broadly civic nationalism. Giving the example of France, he argues that cultural unity can be construed as an expression of political unity, which is in contrast to its role in ethnic nationalism as a primordial basis for such unity. The point at which minority groups' cultural separateness is seen to violate political unity is precisely the point around which numerous debates are now taking place in several countries. The case of the French ban on religious symbols in public schools is one example.

The cultural definition of nationality (or at least 'language' as its proxy) shows a pattern more similar to what we would expect of 'ethnic' rather than 'civic' nationalism with regard to anti-immigrant prejudice in the current study. This is in line with Hobsbawm's (1990/1992) account of linguistic and ethnic nationalism as closely related historically. It may also be that, in the many contexts where antiracism (or certain versions of anti-racism; see Lentin 2004) has become a dominant discourse, linguistic groups have in some way taken the place of 'races' as essentialized outgroups. Needless to say, the way in which popular notions of culture inform arguments and attitudes about immigration, inclusion and exclusion, and 
especially how they interact with anti-racist norms, is a complex issue worthy of attention from the social sciences.

Like any cross-sectional analysis, the current study does not allow us to make any conclusive statement on the direction of causality between the variables. Existing experimental and longitudinal evidence does indicate that national identification and national definitions have a causal effect on attitudes towards immigrants on an individual level (Esses, Dovidio, Semenya and Jackson 2005; Pehrson et al. in press). At the national level, this is rather more difficult to establish. We must therefore remain open to the possibility of identification-prejudice relationship influencing (or in some sense constituting) particular national definitions.

Some other crucial questions are left unanswered by the current study. For example, the role of institutional factors, such as citizenship policy, is not addressed by our analysis. Attempting to include such factors would have complicated the model beyond what can be achieved with a national-level sample size of only 31 , and, as Bail (2008) notes, not every state has an official 'philosophy of integration'. Questions such as whether policies rather than shared representation of the nation are more influential in shaping attitudes, and the extent to which national definitions shape policy rather than vice versa, lend themselves to more detailed historical analysis. For example, Brubaker (1990) presents a comparative account of two nationstates, France and Germany, in terms of their respective histories of nationalism and citizenship policy. He concludes that the different citizenship regimes in these countries have deep historical roots in French and German understandings of nationhood. Detailed studies of particular states as they implement changes to their citizenship laws would also deepen our understanding of this issue (Bail 2008). The type of analysis that we present here, whilst powerful in some respects, is necessarily 
simplistic in others. It is certainly not meant as a substitute for other kinds of scholarship on the issue.

Similarly, we have not attempted to model the role of actual migration flows to each country. Multilevel regression does not lend itself to exploratory analysis. Our intention was to test some clear hypotheses about the variability of the identificationprejudice relationship rather than to model the full complexity of migration, national identity and prejudice. However, complex relationships do exist between the extent and recency of migration to European countries and the types of 'symbolic boundaries' supported by the population (Bail 2008). We acknowledge, therefore, that national definitions and associations between national identification and prejudice are both likely to be influenced by countries' experiences of migration, and it is entirely plausible that this impacts on what we have observed here.

The availability of international survey data on attitudes about immigrants and immigration presents an opportunity to examine the contextual variability in psychological processes determining anti-immigrant sentiment. The current study utilizes one such dataset, and appropriate multilevel statistical methods, to demonstrate not only that national identification shows a variable relationship with anti-immigrant prejudice, but also that this variability can be partly accounted for by measurable contextual differences in how nationality is defined by different populations. This contributes towards a fuller understanding of an important political issue, and addresses Tajfel's (1981: 24) observation that:

“... 'interaction' [between psychological and social phenomena] is merely a useless slogan unless it can be translated into a way of thinking about research 
problems and unless it determines the manner in which research is conducted.".

It is hoped that further multilevel theorising and analysis in the future will contribute towards a social psychology that fulfils this condition. 


\section{REFERENCES}

Allport, Gordon W. 1954a. "The Historical Background of Modern Social Psychology." in Handbook of Social Psychology, Vol 1:Theory and Method, edited by G. Lindzey: Addison-Wesley.

—. 1954b. The Nature of Prejudice. Cambridge MA: Addison-Wesley.

Anderson, Benedict. 1983/1991. Imagined Communities: Reflections on the origins and spread of nationalism. London: Verso.

Bail, Christopher A. 2008. "The Configuration of Symbolic Boundaries against Immigrants in Europe". American Sociological Review 73(Feb):37-59

Billig, Michael. 1991. Ideology and Opinions: Studies in Rhetorical Psychology. London: Sage.

—. 1995. Banal Nationalism. London: Thousand Oaks.

Bourhis, Richard Y. and Joelle Dayan. 2004. "Acculturation orientations towards Israeli Arabs and Jewish immigrants in Israel." International Journal of Psychology 39:118-131.

Brewer, Marilynn B. 1999. "The Psychology of Prejudice: Ingroup Love or Outgroup Hate." Journal of Social Issues 55:429-444.

Brown, Rupert. 2000. "Social identity theory: past achievements, current problems and future challenges." European Journal of Social Psychology 30:745-778.

Brown, Rupert J and Hanna Zagefka. 2005. "Ingroup Affiliations and Prejudice." Pp. 54-70 in On the Nature of Prejudice: Fifty years after Allport, edited by J. Dovidio, P. Glick, and L. Rudman. Oxford: Blackwell. 
Brubaker, William Rogers. 1990. "Immigration, citizenship, and the nation-state in France and Germany: A comparative historical analysis.” International Sociology, 5:379-407.

Carpenter, James, and Mike Kenward. 2005. Simple ad hoc methods for coping with missing data and their shortcomings. Retrieved from the ESRC Researcher Development Initiative website, http://www.lshtm.ac.uk/msu/missingdata/simple_web/index.html, April 2008.

Central Archive for Empirical Social Research. 2004. ISSP 2003 - National Identity II. Cologne, Germany.

Cheung, Pauline Hope, Rosalind Edwards, Harry Goulbourne and John Solomos. 2007. "Immigration, social cohesion and social capital: A critical review." Critical Social Policy, 27:24-29.

Coenders, Marcel, and Scheepers, Peer. 2003. "The Effect of Education on Nationalism and Ethnic Exclusionism: An International Comparison.” Political Psychology 24:313-343.

Gellner, Ernest. 1983/2006. Nations and Nationalism. Oxford: Blackwell.

Esses, Victoria M., John F. Dovidio, Antoinette Semenya, \& Lynne Jackson. 2005. “Attitudes Towards Immigrants and Immigration: The Role of National and International Identity." In The Social Psychology of Inclusion and Exclusion, edited by D. Abrams, M.A. Hogg, \& J. M. Marques. Hove: Psychology Press. Global Commission for International Migration. 2005. Migration in an interconnected world: New directions for action. Retrieved October 2007 from http://www.gcim.org/attachements/gcim-complete-report-2005.pdf 
Green, Eva G. T. 2007. "Individual and country-level threat defines the perception of a "good immigrant": A multilevel analysis in Europe." Manuscript submitted for publication.

Greenfeld, Liah. 1996. "Nationalism and Modernity. " Social Research 63:3-40.

-. 2006. Nationalism and the Mind: Essays on Modern Culture. Oxford: Oneworld.

Hobsbawm, Erik. 1990/1992. Nations and Nationalism since 1780: Programme, Myth, Reality. Cambridge: Canto.

Hox, Joop. 2002. Multilevel Analysis: Techniques and Applications. London: Lawrence Erlbaum Associates.

Ignatieff, Michael. 1993. Blood and Belonging: Journeys into the New Nationalism. London: Vintage.

Jackson, James S., Kendrick T. Brown, Tony N. Brown, and Bryant Marks. 2001. "Contemporary Immigration Policy Orientations Among Dominant-Group Members in Western Europe." Journal of Social Issues 57:431-456.

Lentin, Alana. 2004. Racism and Anti-Racism in Europe. London: Pluto Press.

Livingstone, Andrew and S. Alexander Haslam. 2008. "The importance of social identity content in a setting of chronic social conflict: Understanding intergroup relations in Northern Ireland." British Journal of Social Psychology, 47:1-21.

Maddens, Bart, Jaak Billiet, and Roeland Beerten. 2000. "National identity and the attitude towards foreigners in multi-national states: the case of Belgium." Journal of Ethnic and Migration Studies 26:45-60.

McLaren, Lauren M. 2003. "Anti-immigrant prejudice in Europe: Contact, Threat Perception, and Preferences for the Exclusion of Migrants." Social Forces 81:909-936. 
Mummendey, Amelie, Andreas Klink, and Rupert J Brown. 2001. "Nationalism and patriotism: National identification and out-group rejection." British Journal of Social Psychology 40:159-172.

Parker, Ian. 1992. Discourse dynamics: Critical analysis for social and individual psychology. London, UK: Routledge.

Pehrson, Samuel, Rupert Brown, and Hanna Zagefka. In press. "When does national identification lead to the rejection of immigrants? Cross-sectional and longitudinal evidence for the role of essentialist ingroup definitions." British Journal of Social Psychology.

Pettigrew, Thomas F. 2006a. "The advantages of multilevel approaches." Journal of Social Issues 62:615-620.

—. 2006b. "A Two-Level Approach to Anti-Immigrant Prejudice and Discrimination." Pp. 95-112 in Cultural Psychology of Immigrants, edited by R. Mahalingam: Lawrence Erlbaum.

Pettigrew, Thomas F., Ulrich Wagner, and Oliver Christ. 2007. "Who Opposes Immigration?: Comparing German with North American findings." The Dubois Review 4:19-39.

Raudenbush, Stephen, Anthony Bryk, and Richard Congdon. 2007. "HLM 6: Hierarchical Linear and Nonlinear Modeling." Lincolnwood, IL: Scientific Software International.

Reicher, Stephen. 2004. "The Context of Social Identity: Domination, Resistance and Change." Political Psychology 25:921-945.

Reicher, Stephen and Nick Hopkins. 2001. Self and Nation. London: Sage. 
Rothi, Despina M, Evanthia Lyons, and Xenia Chryssochoou. 2005. "National Attachment and Patriotism in a European Nation: A British Study." Political Psychology 26:135-155.

Shulman, Stephan. 2002. "Challenging the civic/ethnic dichotomies in the study of nationalism." Comparative Political Studies 35:554-585.

Smith, Anthony D. 2001. Nationalism: Theory, ideology, history. Cambridge: Polity Press.

Smith, Peter B. 2004. "Acquiescent Response Bias as a Function of Cultural Communication Style." Journal of Cross-Cultural Psychology 35:50-61.

Sumner, William G. 1906. Folkways. New York: Ginn.

Tajfel, Henri. 1981. Human Groups and Social Categories: Studies in Social Psychology. Cambridge: Cambridge University Press.

Tajfel, Henri and John C. Turner. 1979. "An integrative theory of intergroup conflict." Pp. 33-47 in The Psychology of Intergroup Relations, edited by W. Austin and S. Worchel. Monterey, CA: Brookes Cole.

Tilly, James, Sonia Exley and Anthony Heath. 2004. "Dimensions of British identity.” In British Social Attitudes: The $21^{\text {st }}$ Report, edited by A. Park, J. Curtice, K. Thomson, C. Bromley and M. Phillips. London: Sage.

Verkuyten, Maykel. 2004. "Multiculturalism and group status: The role of ethnic identification, group essentialism and protestant ethic." European Journal of Social Psychology 34:647-661.

Weldon, Steven A. 2006. "The Institutional Context of Tolerance for Ethnic Minorities: A Comparative, Multilevel Analysis of Western Europe”. American Journal of Political Science 50:331-349. 


\section{AUTHOR BIOGRAPHIES}

Samuel Pehrson recently completed his doctoral research at the University of Sussex, UK, and is now a post-doctoral researcher at the University of Limerick, Ireland. He is primarily interested in social identity approaches to topics such as nationalism, racism, the politics of immigration, and the construction and contestation of social categories.

Vivian L. Vignoles is Senior Lecturer in Social Psychology at Sussex University, UK. His primary research interests are in self and identity, especially motivational processes and the influence of culture and context on identity construction, as well as developing a better understanding of the relationship between individual and social representation processes.

Rupert Brown is Professor of Social Psychology at Sussex University, UK. He is the author of Group Processes (Blackwell, 2000) and Prejudice: its Social Psychology (Blackwell, 1995) and more than 100 other articles and chapters. His research interests are in the social psychology of intergroup relations, especially prejudice and its reduction, immigration and post-conflict reconciliation. 
TABLE 1: Pearson's correlation between national identification and prejudice for each national sample included in the analysis.

\begin{tabular}{|c|c|c|c|c|c|}
\hline Country & $\begin{array}{r}\text { Sample } \\
\text { size }\end{array}$ & $\begin{array}{r}\text { National } \\
\text { identification } \\
(\text { mean level) }\end{array}$ & $\begin{array}{r}\text { Prejudice } \\
\text { (mean level) }\end{array}$ & $\begin{array}{r}\text { ide } \\
\text { prejudice }\end{array}$ & $\begin{array}{r}\text { National } \\
\text { atification- } \\
\text { correlation }\end{array}$ \\
\hline Venezuela & 1114 & $3.68(.46)$ & $2.91(.69)$ & -0.06 & $*$ \\
\hline Canada & 1014 & $3.48(.62)$ & $2.78(.75)$ & -0.04 & \\
\hline Israel & 1177 & $3.46(.68)$ & $3.10(.95)$ & 0.00 & \\
\hline New Zealand & 906 & $3.62(.49)$ & $3.05(.75)$ & 0.01 & \\
\hline Czech Republic & 1089 & $3.13(.60)$ & $3.73(.68)$ & 0.01 & \\
\hline Portugal & 1491 & $3.48(.51)$ & $3.11(.73)$ & 0.02 & \\
\hline Chile & 1446 & $3.61(.48)$ & $3.31(.66)$ & 0.02 & \\
\hline Russia & 2181 & $3.02(.70)$ & $3.71(.83)$ & 0.03 & \\
\hline Taiwan & 1906 & $3.20(.64)$ & $3.43(.62)$ & 0.03 & \\
\hline Ireland & 1005 & $3.60(.48)$ & $3.18(.77)$ & 0.04 & \\
\hline Hungary & 986 & $3.55(.46)$ & $3.67(.69)$ & 0.04 & \\
\hline South Korea & 1291 & $3.10(.61)$ & $2.81(.59)$ & 0.05 & $\dagger$ \\
\hline Uruguay & 1065 & $3.56(.53)$ & $2.74(.66)$ & 0.06 & $\dagger$ \\
\hline United States & 1138 & $3.59(.52)$ & $3.10(.78)$ & 0.08 & ** \\
\hline Poland & 1219 & $3.36(.56)$ & $3.35(.65)$ & 0.09 & ** \\
\hline Slovak Republic & 1067 & $3.22(.61)$ & $3.38(.69)$ & 0.13 & ** \\
\hline Great Britain & 766 & $3.17(.70)$ & $3.48(.78)$ & 0.14 & $* *$ \\
\hline Slovenia & 1061 & $3.45(.51)$ & $3.25(.70)$ & 0.15 & $* *$ \\
\hline Sweden & 1095 & $3.21(.60)$ & $3.00(.83)$ & 0.16 & ** \\
\hline Japan & 1041 & $3.36(.58)$ & $3.31(.81)$ & 0.18 & ** \\
\hline Australia & 1964 & $3.53(.55)$ & $2.79(.78)$ & 0.19 & $* *$ \\
\hline East Germany & 412 & $2.87(.62)$ & $3.60(.79)$ & 0.19 & $* *$ \\
\hline Netherlands & 1659 & $3.00(.65)$ & $3.21(.76)$ & 0.19 & *** \\
\hline France & 1399 & $3.28(.64)$ & $3.15(1.03)$ & 0.20 & $* *$ \\
\hline Austria & 934 & $3.47(.58)$ & $3.37(.90)$ & 0.20 & $* *$ \\
\hline Finland & 1239 & $3.34(.56)$ & $3.17(.84)$ & 0.21 & $* *$ \\
\hline Spain & 1142 & $3.12(.74)$ & $3.01(.66)$ & 0.26 & $* *$ \\
\hline Norway & 1329 & $3.28(.57)$ & $3.37(.77)$ & 0.29 & $* *$ \\
\hline Switzerland & 892 & $3.25(.61)$ & $2.94(.69)$ & 0.31 & $* *$ \\
\hline West Germany & 735 & $2.92(.65)$ & $3.39(.78)$ & 0.35 & $* *$ \\
\hline Denmark & 1267 & $3.34(.56)$ & $3.13(.91)$ & 0.37 & ** \\
\hline
\end{tabular}

Note:

${ }^{\dagger} \mathrm{p} \leq .10 ;{ }^{*} \mathrm{p} \leq .05 ;{ }^{* *} \mathrm{p} \leq .01$ (two-tailed). 
TABLE 2: Descriptive statistics and Pearson's correlations at individual (above diagonal) and national (below diagonal) levels.

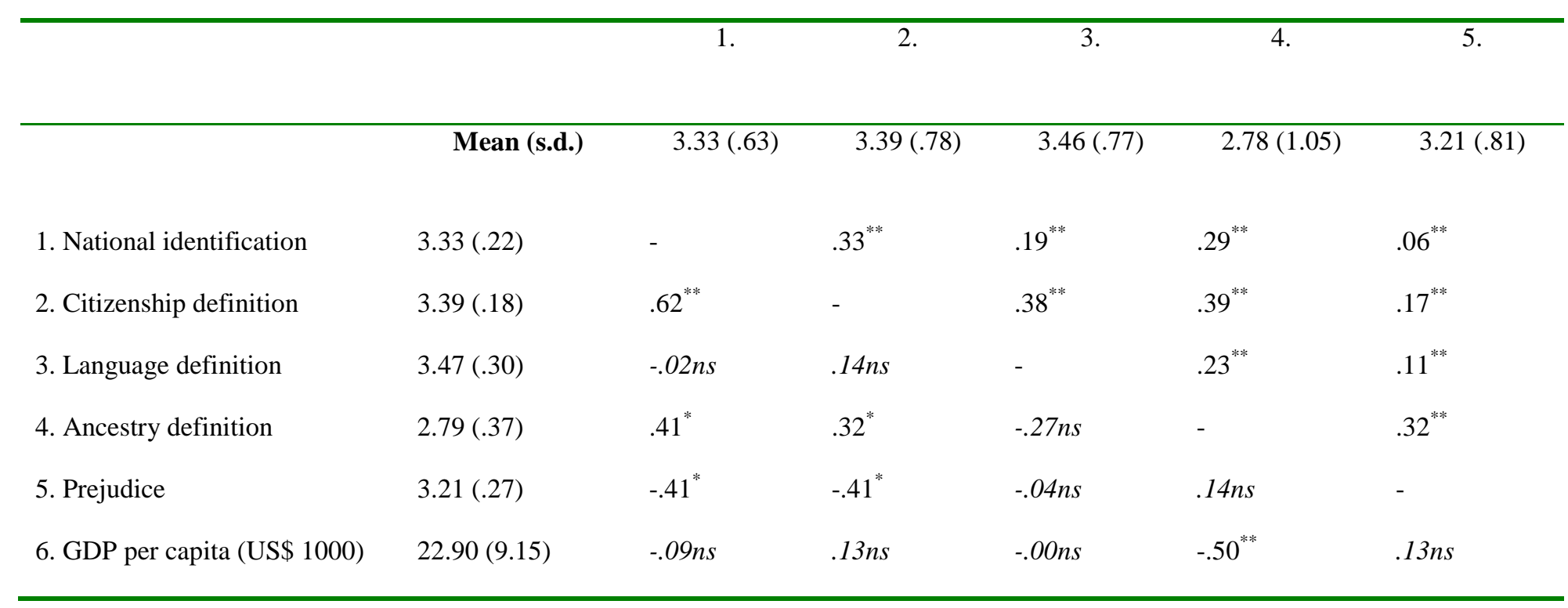

Note:

${ }^{\dagger} \mathrm{p} \leq .10 ;{ }^{*} \mathrm{p} \leq .05 ;{ }^{* *} \mathrm{p} \leq .01$ (two-tailed). 
TABLE 3: Multilevel regression predicting anti-immigrant prejudice.

\begin{tabular}{|c|c|c|c|c|c|c|c|c|c|c|c|c|c|c|c|}
\hline & \multicolumn{3}{|c|}{$\begin{array}{c}\text { Model } 1 \\
{[7 \mathrm{df}]}\end{array}$} & \multicolumn{3}{|c|}{$\begin{array}{c}\text { Model } 2 \\
\text { [9df] }\end{array}$} & \multicolumn{3}{|c|}{$\begin{array}{c}\text { Model } 3 \\
{[15 \mathrm{df}]}\end{array}$} & \multicolumn{3}{|c|}{$\begin{array}{c}\text { Model } 4 \\
\text { [19df] }\end{array}$} & \multicolumn{3}{|c|}{$\begin{array}{l}\text { Model } 5 \\
\text { [22df] }\end{array}$} \\
\hline & B & S.E. & $\beta$ & B & S.E. & $\beta$ & B & S.E. & $\beta$ & B & S.E. & $\beta$ & B & S.E. & $\beta$ \\
\hline \multicolumn{16}{|l|}{$\begin{array}{l}\text { Individual level } \\
(\mathbf{N}=\mathbf{3 7}, \mathbf{0 3 0})\end{array}$} \\
\hline Age & .02 & .01 & $.04^{*}$ & .01 & .01 & $.03^{* *}$ & -.01 & .01 & -.01 & -.01 & .01 & -.01 & .01 & .01 & -.01 \\
\hline Education & -1.85 & .14 & $-.23^{* *}$ & -1.80 & .13 & $-.22^{* *}$ & -1.46 & .09 & $-.18^{* *}$ & -1.45 & .09 & $-.18^{* *}$ & -1.45 & .09 & $-.18^{* * *}$ \\
\hline Income & -.54 & .07 & $-.07^{* *}$ & -.54 & .07 & $-.07^{* * *}$ & -.42 & .07 & $-.05^{* *}$ & -.43 & .06 & $-.05^{* * *}$ & -.42 & .07 & $-.05^{* *}$ \\
\hline National identification & & & & 1.15 & .24 & $.09^{* *}$ & .01 & .15 & .00 & .06 & .19 & .00 & .09 & .19 & .01 \\
\hline Citizenship definition & & & & & & & .81 & .13 & $.08^{* * *}$ & .78 & .13 & $.07^{* * *}$ & .78 & .13 & $.08^{* * *}$ \\
\hline Linguistic definition & & & & & & & .20 & .17 & .02 & .24 & .17 & .02 & .23 & .17 & .02 \\
\hline Ancestry definition & & & & & & & 1.97 & .20 & $.26 * *$ & 1.95 & .20 & $.25^{* *}$ & 1.95 & .20 & $.25^{* *}$ \\
\hline Citizenship * Identification & & & & & & & & & & -.03 & .06 & .00 & .02 & .06 & .00 \\
\hline Linguistic * Identification & & & & & & & & & & .08 & .08 & .01 & .02 & .08 & .00 \\
\hline Ancestry * Identification & & & & & & & & & & -.05 & .08 & -.01 & -.03 & .07 & .00 \\
\hline \multicolumn{16}{|l|}{ National level ( $N=31)$} \\
\hline GDP & -.04 & .06 & -.15 & -.05 & .05 & -.18 & .04 & .05 & .14 & .04 & .05 & .12 & .04 & .05 & .13 \\
\hline National identification & & & & -6.42 & 1.95 & $-.52^{* *}$ & -4.60 & 2.89 & -.38 & -4.55 & 2.84 & -.37 & -4.77 & 2.82 & $-.39^{\dagger}$ \\
\hline
\end{tabular}




\begin{tabular}{|c|c|c|c|c|c|c|c|c|c|c|c|}
\hline & $\begin{array}{c}\text { Model } 1 \\
{[7 \mathrm{df}]}\end{array}$ & $\begin{array}{c}\text { Model } 2 \\
\text { [9df] }\end{array}$ & & $\begin{array}{c}\text { Model } 3 \\
{[15 \mathrm{df}]}\end{array}$ & & & $\begin{array}{c}\text { Model } 4 \\
{[19 \mathrm{df}]}\end{array}$ & & & $\begin{array}{r}\text { Model } 5 \\
\text { [22df] }\end{array}$ & \\
\hline Citizenship definition & & & -6.39 & 3.17 & $-.43^{*}$ & -6.51 & 3.05 & $-.43^{*}$ & -6.10 & 2.96 & $-.41^{*}$ \\
\hline Linguistic definition & & & .98 & 1.24 & .11 & 1.17 & 1.23 & .13 & 1.07 & 1.22 & .12 \\
\hline Ancestry definition & & & 1.73 & 1.31 & .24 & 1.77 & 1.31 & .24 & 1.77 & 1.30 & .24 \\
\hline \multicolumn{12}{|c|}{$\begin{array}{l}\text { National level moderators } \\
\text { of identification slope }\end{array}$} \\
\hline GDP & & & & & & .08 & .02 & $.57^{* *}$ & .09 & .02 & $.65^{* *}$ \\
\hline Citizenship definition & & & & & & & & & -3.49 & 1.23 & $-.49^{* *}$ \\
\hline Linguistic definition & & & & & & & & & 1.21 & .55 & $.29^{*}$ \\
\hline Ancestry definition & & & & & & & & & .36 & .54 & .10 \\
\hline \multicolumn{12}{|l|}{ Residual variance } \\
\hline Individual level $\left(\sigma^{2}\right)$ & .5381 & .5337 & & .4901 & & & .4882 & & & .4872 & \\
\hline Nation level $\left(\tau^{2}\right)$ & .0696 & .0566 & & .0461 & & & .0448 & & & .0444 & \\
\hline \multicolumn{12}{|l|}{$\begin{array}{l}\text { Modelled variance } \\
\text { (percent) }\end{array}$} \\
\hline $\mathrm{R}^{2}{ }_{\text {within }}$ & 8.1 & 8.9 & & 16.3 & & & 16.6 & & & 16.8 & \\
\hline $\mathrm{R}_{\text {between }}^{2}$ & 1.9 & 20.1 & & 34.8 & & & 36.7 & & & 37.2 & \\
\hline $\mathrm{R}_{\text {overall }}^{2}$ & 7.4 & 10.1 & & 18.3 & & & 18.8 & & & 20.6 & \\
\hline Deviance & 82292 & 81982 & & 78821 & & & 78676 & & & 78605 & \\
\hline
\end{tabular}




\begin{tabular}{lcccc}
\hline & Model 1 & Model 2 & Model 3 & Model 5 \\
{$[7 \mathrm{df}]$} & {$[9 \mathrm{df}]$} & {$[15 \mathrm{df}]$} & $3162^{* *}$ & {$[19 \mathrm{df}]$} \\
\hline Likelihood Ratio & $3135^{* *}$ & $310^{* *}$ & $145^{* *}$ & $71^{* *}$ \\
\hline
\end{tabular}

Notes:

Un-standardized betas and robust standard errors have all been multiplied by 10 for efficiency of presentation. Standardized betas for the cross-level interactions were computed using the standard deviation of the identification slope that is obtained when a random intercept is added to model 3. None of the reported models include a random slope because of the hypothesis-driven nature of the analysis. ${ }^{\dagger} \mathrm{p} \leq .10 ;{ }^{*} \mathrm{p} \leq .05 ;{ }^{* *} \mathrm{p} \leq .01$ (two-tailed). 